\title{
Reakcja Chińskiej Republiki Ludowej na wojnę hybrydową w Syrii
}

\section{The People's Republic of China's Response to the Hybrid War in Syria}

\section{Abstract}

The main purpose of the paper is to present the most important determinants and dependencies characterizing the policy of the People's Republic of China towards hybrid war in Syria since 2011. The paper starts with the definition of hybrid war and its most important determinants. In next part of the article, the role Syria that plays in China's political strategy has been described. At the outset, relations between Beijing and Damascus during the Cold War and immediately after its completion have been analyzed, when the Chinese side approached with a considerable distance to wider involvement in the Middle East, including Syria, having own internal difficulties, tense relations with the United States and the pro-soviet and then pro-russian position of Damascus. Next, Beijing's views on the outbreak of the war in Syria have been mentioned, pointing to the most important determinants of the Chinese politics and the ideas for resolving it proposed by the Chinese Communist Party. In addition, goals that the Middle Kingdom wants to achieve in Syria have been presented in the global and economic aspect. The attitude of the communist power to the problem of rebuilding Syria has also been put into account. In conclusion, it has been addressed whether in the era of China's growing assertiveness on the international arena, a modification of the Chinese position, should be expected.

Keywords: People's Republic of China, Syria, hybrid war, politics, Bashar al-Assad, Xi Jinping 


\section{Реакция Китайской Народной Республики на гибридную войну в Сирии}

\section{Аннотачия}

Основная цель статьи - представить наиболее важные детерминанты и зависимости, характеризующие политику Китайской Народной Республики в отношении гибридной войны в Сирии с 2011 года. Была предпринята попытка объяснить определение гибридной войны и ее важнейшие детерминанты. В следующей части статьи была описана роль Сирии в политической стратегии Китая. Вначале проанализировано отношения между Пекином и Дамаском во время холодной войны и сразу после ее завершения, когда китайская сторона воздерживалась от более широкого вмешательства на Ближнем Востоке, в том числе в Сирии, имея собственные внутренние трудности, напряженные отношения с США, а также из-за просоветской, а затем пророссийской позиции Дамаска. Далее была прослежена точка зрения Пекина на начало войны в Сирии, указаны наиболее важные детерминанты китайской политики и идеи по решению этого вопроса, предложенные Коммунистической партией Китая. Были указаны цели, которые Китай хочет достичь в Сирии, принимая во внимание глобальный и экономический аспект. Кроме того, было представлено отношение коммунистической власти к проблеме восстановления Сирии. Заключение статьи содержит прогнозы, стоит ли, в эпоху растущей роли Китая на международной арене, ожидать изменения позиции Китая по отношению к конфликту.

Ключевье слова: Китайская Народная Республика, Сирия, гибридная война, политика, Башар аль-Асад, Си Цзиньпин

\section{Wprowadzenie}

statnie wydarzenia międzynarodowe, związane z osłabieniem pozycji Stanów Zjednoczonych i rosnącą rolą Chin, obligują do przybliżenia stanowiska dyplomacji Państwa Środka wobec konfliktów światowych. Jednym z takich sporów jest wojna w Syrii, trwająca od 2011 r.W niniejszym artykule przybliżone zostanie stanowisko Chińskiej Republiki Ludowej (ChRL) wobec działań wojennych w tym kraju do chwili obecnej. Przeanalizowanie opisywanego zagadnienia jest spowodowane niedostatecznym zarysowaniem problemu w polskim dyskursie naukowym. Dodatkowo uwzględnione zostanie pytanie, czy Chiny będą w najbliższym czasie intensyfikować kontakty z Syrią w obliczu osłabienia pozycji USA i powrotu aktywnej polityki Rosji na Bliskim 
Wschodzie. Osiągnięcie wszystkich powyższych zamierzeń pozwoli na zweryfikowanie następującej hipotezy: dyplomacja chińska w Syrii w sferze politycznej dąży do unikania wgłębiania się w tamtejsze spory, natomiast w wymiarze ekonomicznym odznacza się rosnącą dynamiką. W niniejszych rozważaniach należy postawić następujące pytania badawcze: co to jest wojna hybrydowa i jakie są jej najważniejsze determinanty? Jak wyglądały stosunki chińsko-syryjskie od początku zimnej wojny do 2011 r.? Jakie podejście reprezentowały Chiny na początku protestów? Jakie są najważniejsze determinanty globalne chińskiego zaangażowania w Syrii w odniesieniu do relacji ze Stanami Zjednoczonymi i Rosją? Jakie są zależności ekonomiczne obu krajów? Czy chiński rząd jest zainteresowany wsparciem ekonomicznym dla państwa rządzonego przez prezydenta Baszara al-Asada po zakończeniu działań wojennych? Jak będą w przyszłości wyglądały więzi obu podmiotów? W badaniach przyjęto metodę analizy czynnikowej. Tytułem wstępu zaprezentowane zostanie pojęcie wojny hybrydowej i jej najważniejsze założenia.

\section{Istota i pojęcie „wojny hybrydowej”}

Na wstępie niniejszego tekstu warto przybliżyć definicję wojny hybrydowej. Termin spopularyzował Jewgienij Messner - jeden z rosyjskich wojskowych, służący w armii carskiej, według którego można utożsamiać ją z „wojnami buntowniczymi”. W przekonaniu Messnera wojny hybrydowe charakteryzują się działaniami militarnymi o ograniczonym zasięgu, mającymi na celu przede wszystkim wywołanie chaosu w danych państwach poprzez środki masowego przekazu, a także próbę poróżnienia narodu będącego ofiarą agresji (Ochmann, Wojas, 2018, s. 102). Chociaż jeszcze w okresie zimnej wojny dominowały tradycyjne metody walki, to wraz z rozwojem technologii i cybernetyki od początku XXI wieku sposoby prowadzenia wojny zaczęły stopniowo ewoluować, głównie za sprawą wojny w Afganistanie, Iraku oraz konfliktu w Czeczenii. Nieprzypadkowo w 2002 r. William J. Nemeth definiował wszelkiego rodzaju hybrydowość nie tylko pod kątem działań rosyjskich, ale także postawy Czeczeńców, gdyż działania Rosjan służyły nie tyle określonym celom militarnym, ale także dążeniom do złamania narodu czeczeńskiego i chęci zmiany sposobu funkcjonowania tego społeczeństwa, w tym jego obyczajowości (Skoneczny, 2009, s. 40). 
Z kolei Frank Hoffman sugerował, że zagrożenie hybrydowe powinniśmy rozpatrywać nie tylko na płaszczyźnie militarnej, ale także poprzez swoistą kombinację broni konwencjonalnej, taktyki oraz terroryzmu. Analityk twierdził także, że połączenie tych metod ma na celu realizację określonych celów na płaszczyźnie politycznej poprzez działalność dezinformacyjną, propagandową i terrorystyczną ze strony państwa, a także aktywność struktur pozapaństwowych, co ma stanowić niejako uzupełnienie działań w sferze militarnej (Smoleń, 2020, s. 219). Autor nadmienił też, że działania hybrydowe mają na celu także wywołanie rozbieżności opinii publicznej w celu wywołania chaosu i osłabienia zdolności strategicznych (Gostomczyk, 2017, s. 63). Wraz z upływem czasu używano coraz to nowszych form walki, czego wyrazem były konflikty, szczególnie w Gruzji w 2008 r., na Ukrainie od 2014 r. czy wreszcie w Libii, gdzie finansowana przez Rosję Grupa Wagnera walczyła po stronie rebeliantów, skupionych wokół gen. Chalifa Haftara. Jak podaje Katarzyna Grabowska, hybrydowość współczesnych działań wojennych jest postrzegana zarówno na płaszczyźnie terytorialnej, jak i wirtualnej, w której szczególną rolę odgrywa dezinformacja i szerzenie propagandy zgodnie z interesami agresora (Grabowska, 2015, s. 277).Z rozwinięciem instrumentów prowadzenia wojny mamy również do czynienia w konflikcie syryjskim, w którym, obok Stanów Zjednoczonych, Rosji, Iranu i Turcji, istotną rolę odgrywają Chiny. Poniżej przeanalizowana zostanie historia stosunków Państwa Środka z Syrią.

\section{Historia stosunkow chińsko-syryjskich w latach 1946-2011}

Omawiając stanowisko Chin wobec wojny domowej w Syrii, warto zaznaczyć, że oba kraje utrzymywały formalne kontakty od momentu uznania przez rząd Chang Kaj-Szeka niepodległości Syrii w kwietniu 1946 r. Jednakże dopiero w sierpniu 1956 r. oba kraje utworzyły wzajemnie swoje ambasady (Zreik, 2019, s. 57). Mimo wszystko ich związki w tym czasie nie były zbyt ożywione. Złożyło się na to kilka czynników. Po pierwsze, rządzący krajem od października 1949 r. przywódca Komunistycznej Partii Chin (KPCh) Mao Zedong chciał w pierwszych latach urzędowania umocnić panowanie nad krajem i wprowadzić komunistyczny system gospodarczy. W celu zmaterializowania swoich zamysłów chiński 
przywódca zdecydował się przejściowo zawrzeć sojusz ze Związkiem Radzieckim, prowadząc politykę izolacjonistyczną wobec innych obszarów, w tym Bliskiego Wschodu. Ponadto nie bez racji postrzegał on przedmiotowy obszar jako pole rywalizacji krajów anglosaskich oraz ZSRR, w którą Chiny wolały się nie angażować. Sytuacja zaczęła się zmieniać na przełomie lat 60. i 70. XX wieku, kiedy to znacząco pogorszyły się stosunki na linii Moskwa-Pekin, co skutkowało starciami granicznymi między siłami zbrojnymi obu mocarstw w 1969 r. W tej sytuacji Państwo Środka dążyło do zaznaczenia swojej obecności na Bliskim Wschodzie. Wymowna była wizyta ówczesnego szefa sztabu armii Syrii Mustafy Tlassa w Pekinie, zaledwie 2 miesiące po potyczkach militarnych między ChRL a ZSRR. Jeszcze większe zdziwienie budził fakt, że został on sfotografowany z Czerwoną Książeczką Mao Zedonga (Freedman, 1982, s. 34). Po drugie, wraz z dojściem do władzy Hafeza Al-Asada w 1970 r. (po przewrocie wojskowym), Syria przyjęła zdecydowanie proradziecką orientację w polityce zagranicznej, co siłą rzeczy spowodowało niechęć dyktatora do zacieśnienia kontaktów z Chinami. Mimo wszystko, wraz z początkiem lat 80 . XX wieku i stopniową deprecjacją gospodarki ZSRR oraz niechęcią tego państwa do szerszego angażowania się w konflikty na Bliskim Wschodzie, np. wojny w Libanie, prezydent Syrii dążył do uzyskania poparcia Chin dla rozwoju potencjału nuklearnego swego kraju. Po trzecie, wraz z dojściem do władzy Deng Xiaopinga, Chiny powoli zwiększały zakres kontaktów z krajami Bliskiego Wschodu, niezależnie od ich orientacji politycznej i ideologicznej. Chociaż Chiny nawiązały szczególnie więzi z Iranem, to jednak starały się nie zrażać do siebie poszczególnych krajów regionu. Okoliczności uległy pewnej zmianie po stłumieniu protestów studentów na placu Tiananmen w Pekinie przez Chińską Armię Ludowo-Wyzwoleńczą (ChALW) w czerwcu 1989 r. Będąc wówczas w ograniczonej izolacji międzynarodowej, Chiny zaczęły wspierać militarnie kraje arabskie, nastawione antyamerykańsko, czego dowodem było podpisanie umowy z Iranem odnośnie do kooperacji w zakresie energetyki jądrowej. Co prawda, umowa formalnie dotyczyła energetyki cywilnej, jednak nie można wykluczyć, że za sprawą chińskiej pomocy Iran zwiększył swój potencjał wojskowy (Jureńczyk, 2018, s. 35). Podobna sytuacja miała miejsce w Syrii. Już w sierpniu tegoż roku pojawiły się doniesienia o zamówieniu w Chinach przez władze w Damaszku pocisków M-9 (Cordesman, 2000, s. 2). Informacje 
na temat sprzedawania technologii rakietowych Syrii od początku lat 90. XX wieku potwierdza także analityczka ds. Chin, Patrycja Pendrakowska (Pendrakowska, 2016). Niemniej jednak, w kolejnych latach wzajemny alians nie przybrał znaczącego charakteru. Chcąc zmienić ten stan rzeczy, w październiku 1999 r. ówczesny szef chińskiego resortu obrony, gen. Chi Haotian, spotkał się w Damaszku z jego wspomnianym wcześniej odpowiednikiem, Mustafą Tlassem. Omawiano wtedy możliwość rozwinięcia kooperacji obu państw na płaszczyźnie militarnej (Yu-Shek, 2016, s. 565). Niezależnie od powyższych komunikatów, ich współpraca pozostawała jedynie w sferze ogólnych deklaracji i nie oznaczała nawiązania szerszych więzi między oboma państwami. Podejście ChRL wobec Syrii stanowiło niejako odbicie polityki zagranicznej Chin, realizowanej stricte na podstawie zasady 24 znaków, sformułowanej w 1984 r. przez Denga. Zakładała ona konieczność „spokojnej” obserwacji przez Chiny sytuacji międzynarodowej i nie afiszowania się ze swoją pozycją polityczną i gospodarczą (Sokala, 2008, s. 33; Marszałek-Kawa, 2014; Marszałek-Kawa, Dmochowski, 2018). Koncepcja ówczesnego chińskiego przywódcy była realizowana do objęcia przez Hu Jintao w 2002 r. funkcji sekretarza generalnego Komunistycznej Partii Chin i przewodniczącego ChRL. Od tego momentu rządzący w Pekinie podkreślali chęć intensyfikacji swojej obecności na arenie międzynarodowej, opartej na dążeniu do pokoju na świecie, neutralności i kooperacji między innymi państwami, przy jednoczesnym unikaniu aktywności w kwestiach politycznych. W tym czasie, realizując strategię „zrównoważonego Bliskiego Wschodu", Chiny dążyły do zachowania istniejącej sytuacji w regionie, skupiając się na rozwoju kontaktów ekonomicznych z każdym państwem na przedmiotowym obszarze (Czornik, 2020, s. 123).

\section{Uwarunkowania reakcji ChRL na wojnę hybrydową w Syrii}

Analizując reakcję Chin na wojnę hybrydową w Syrii, trzeba zaakcentować, że chińscy przywódcy przyjęli podobną retorykę, jak we wszystkich krajach regionu Bliskiego Wschodu. Z jednej strony starali się formalnie zdystansować się od zachodzących tam wydarzeń, nie chcąc antagonizować żadnej ze stron, ale z drugiej - nie chcieli upadku syryjskiego reżimu. Nie ulega wątpliwości, że rząd chiński musiał postępować nad wyraz ostrożnie, gdyż opowiedzenie 
się po jednej ze stron mogłoby przyczynić się do osłabienia pozycji Państwa Środka, wypracowywanej przez wiele lat. Chociaż obecny przywódca Chin Xi Jinping przejawia coraz większą asertywność w polityce międzynarodowej, to w odniesieniu do Bliskiego Wschodu konsekwentnie popiera on politykę swoich poprzedników, zakładającą aktywizację społeczności międzynarodowej na terenie Syrii i zachowanie obecnego prezydenta Syrii u steru rządów. Akcentując pragmatyzm i realizm chińskich dyplomatów, jeden z brytyjskich dziennikarzy powiedział słusznie, że „chińska dyplomacja nie polega wcale na zasadach i ochronie cywilów w odległym kraju, ale na twardym własnym interesie”, pomimo tego, że „cywile nadal giną w Syrii w dziesiątkach” (Geogut, Suzuki, 2020, s. 390-391). Politycy chińscy mieli jednak świadomość, że wszelkie ich radykalne działania mogłyby przyczynić się do podważenia ich pozycji. Potwierdzeniem obaw decydentów w KPCh stały się wydarzenia z 2012 r., kiedy to w kilku państwach arabskich spalono chińskie flagi po zawetowaniu przez rząd w Chinach rezolucji Rady Bezpieczeństwa ONZ, wzywającej do usunięcia Baszara al-Asada (Patey, 2016, s. 2). Według Giorgio Cafiero, od początku wojny Chiny starały się zachować wstrzemięźliwe stanowisko, wyrażając pogląd, że konflikt wymaga rozwiązania politycznego, a kraj potrzebuje procesu transformacji politycznej w oparciu o poszanowanie jedności Syrii i dostarczenie przez społeczność międzynarodową pomocy humanitarnej, lecz nie bezpośrednio pod kontrolą krajów zachodnich (Cafiero, 2020). Można wyrazić pogląd, że chińscy rządzący nie aprobują zbyt dużej aktywności Zachodu w sferze humanitarnej, zdając sobie sprawę, że Zachód może wykorzystywać kryzysy humanitarne w celu osiągnięcia swoich celów geopolitycznych (Patey, s. 1). Wydaje się, że chińskie władze dostrzegają nieskuteczność działania Karty Narodów Zjednoczonych jako nie dającej państwom, ani nawet międzynarodowym organom, prawa do użycia siły przy rozstrzyganiu sporów międzynarodowych, a także mogącą pogwałcić zasadę suwerenności narodowej, równości i nieingerencji w innych państwach, a ta powinna zostać podtrzymana w Syrii (Swaine, 2016, s. 9).

Innym czynnikiem wpływającym na taktykę chińską wobec Asada jest interwencja zachodnia w Libii i upadek rządu Kaddafiego w październiku 2011 r. Nie utożsamiając się z działaniami państw anglosaskich i brutalnością libijskiego dyktatora, Chiny - poprzez roztropną politykę - zamierzały uświadomić pozostałym państwom na Bliskim Wschodzie, że mogą na 
nie liczyć w każdej kryzysowej sytuacji. Rządzący w Pekinie niewątpliwie nie chcieli kolejnej zachodniej interwencji militarnej w regionie, mogącej prowadzić do utworzenia prozachodniego rządu w Libii (Douidri, Krijger, 2018, s. 33) i ograniczenia ich wpływów w Syrii oraz w całym regionie bliskowschodnim. Można mniemać, że władze chińskie obawiały się wymknięcia się protestów spod kontroli i destabilizacji świata arabskiego, co leży w sprzeczności z strategią Chin. Nie będąc zwolennikami impulsywnych rozwiązań, przedstawiciele KPCh uważają, że jedynie rozwiązanie polityczne pomoże rozwiązać nabrzmiałe wcześniej problemy. Podkreślając, że reżim Asada jest prawomocny, od początku konfliktu Chiny wielokrotnie wzywały do powstrzymania walk i przywrócenia pokoju, czego wyrazem było poparcie przez nie rezolucji Rady Bezpieczeństwa ONZ o wysłaniu 30 obserwatorów do Syrii i przedłużeniu mandatu Misji Nadzoru Organizacji Narodów Zjednoczonych (UNSMIS). Przedstawiciele Chin poparli też utworzenie grupy kontaktowej w Syrii oraz plan byłego sekretarza generalnego ONZ Koffiego Annana, w myśl którego należy ustanowić rozejm między wszystkimi walczącymi stronami, pod patronatem ONZ, zapewnić pomoc humanitarną, ewakuację rannych czy nawiązanie rozmów na temat politycznego rozwiązania sporu (Syria zgadza się na plan Annana, 2012). Chiny poparły również plan Lakhdara Brahimiego, następcy Annana. Przedstawił on cztery punkty rozwiązania kryzysu. Po pierwsze, zaangażowane podmioty mają zdwoić wysiłki w celu przezwyciężenia konfliktu i współpracy na rzecz stopniowego powstrzymania przemocy w regionie. Po drugie, wysłannicy ONZ, przy wsparciu organizacji globalnych, winny sporządzić w porozumieniu z nimi plan przemian politycznych w Syrii. Po trzecie, społeczność międzynarodowa będzie wspierać wysiłki Brahimiego, zmierzające do osiągnięcia rzeczywistego postępu w realizacji postanowień konferencji genewskiej. Po czwarte, Brahimi wezwał wszystkie podmioty zaangażowane w wojnę, żeby dostarczyły krajowi pomoc humanitarną (Zreik, 2019, s. 61). Inicjatywa algierskiego dyplomaty nie zmieniła jednak impasu na froncie, ponieważ razem z Moskwą Chiny zawetowały kilka innych rezolucji Rady Bezpieczeństwa, wskazując, że kluczowa jest zasada nieingerowania w sprawy wewnętrzne Syrii. Zdaniem przedstawiciela ChRL przy ONZ Li Baodonga, przykładem takiej ingerencji był głosowany przez Radę dokument dotyczący nałożenia sankcji na syryjski reżim, mogących jego zdaniem pogorszyć sytuację. Polityk 
wyraził pogląd, że kraje zachodnie i Stany Zjednoczone miały w planach pogwałcenie suwerenności Syrii (Szczudlik-Tatar, 2012, s. 1).

Innym przejawem chińskiej aktywności było uchwalenie przez dyplomację ChRL w marcu 2012 r. dokumentu z propozycjami konkretnych rozwiązań pokojowych.W dokumencie można przeczytać, że rząd i opozycja w Syrii powinny natychmiast powstrzymać wszelką przemoc, rozpocząć dialog bez żadnych warunków, umożliwić dostarczanie przez ONZ pomocy humanitarnej, respektować suwerenność i integralność terytorialną Syrii, popierać aktywność dyplomatyczną ONZ oraz Ligi Państw Arabskich na terenie Syrii, a także przestrzegać Karty Narodów Zjednoczonych (China’s Peace Plan for Syria, 2012). Kontynuacją tych działań było spotkanie dyrektora Biura Spraw Zagranicznych Partii Komunistycznej Yanga Jiechi z Brahimim w Pekinie w październiku 2012 r. Powiedział on, że Chiny są bardzo zaniepokojone zachodzącymi wydarzeniami i poszukują przezwyciężenia kryzysu. Dygnitarz zaznaczył, że reprezentowane przez niego państwo zajmuje bezstronne stanowisko w sprawie syryjskiej, opowiadając się za pokojem i stabilnością (Yang Jiechi Elaborates China's, 2012).

Chociaż postawa chińskich władz nie pociągała za sobą żadnych konkretnych działań, to dawała sygnał, że kraj wyraża zainteresowanie konfliktem w Syrii (Yellinek, 2020). Zdaniem analityka Ośrodka Studiów Wschodnich Marcina Kaczmarskiego, Chiny stosują taktykę werbalnego wsparcia reżimu prezydenta Asada i walczących po jego stronie sił rosyjskich, ale też uznają konieczność wypracowania kompromisu politycznego między wszystkimi stronami tego konfliktu (Kaczmarski, 2016). W latach 2014-2016 Chiny kontynuowały swoją politykę wobec Syrii, lecz w tym czasie coraz częściej pojawiały się głosy o potajemnym wspieraniu rządu w Damaszku. Podstawą do takich stwierdzeń mogą być słowa Davida Volodzko. Akcentował on, że importowana w 2014 r. przez Teheran broń z Państwa Środka trafiła częściowo do armii rządowej i została wykorzystana przeciwko rebeliantom. Reżim w Pekinie miał przekazać wyrzutnie rakietowe (Voolodzko, 2015). Jednocześnie władze chińskie zintensyfikowały swoje wysiłki dyplomatyczne. Oznaką tego było wystąpienie szefa chińskiej dyplomacji Wanga Yi w czasie II konferencji genewskiej w styczniu 2014 r. w sprawie Syrii. W trakcie obrad chiński dyplomata zaproponował pięć zasad, mających służyć podpisaniu kompleksowej ugody. Jego zdaniem kwestia Syrii powinna być rozwiązana 
środkami politycznymi, a o przyszłości kraju miałby zadecydować naród syryjski. Wang precyzował, że trzeba promować proces pojednania narodowego i jedności terytorialnej państwa. Dodał też, że pomoc humanitarna musi być świadczona w Syrii i krajach sąsiednich (Calabresse, 2019). Wprawdzie na pozór powyższe sformułowania nie odbiegały od wcześniejszego stanowiska Państwa Środka, jednak wydaje się, że, mając świadomość rosyjskiej agresji, Chiny nie chcą pozostać bierne w omawianym konflikcie.

Zwiększenie zaangażowania Chin w Syrii można datować na 2016 r., co wiązało się nie tylko ze wzrostem znaczenia globalnego Federacji Rosyjskiej na Bliskim Wschodzie, ale też z rosnącą asertywnością ChRL w stosunkach ze Stanami Zjednoczonymi i zaostrzaniem polityki reżimu po utrwaleniu władzy przez prezydenta Xi Jinpinga. Chociaż Chiny formalnie dystansowały się od działań Rosji, poszlaki pozwalają stwierdzić, że oba mocarstwa autorytarne wspierają wraz z Iranem obecnego prezydenta Syrii. Sygnałem do tego było mianowanie przez Chiny w marcu 2016 r. specjalnego wysłannika do Syrii, będącego w przeszłości ambasadorem w Iranie (Zreik, 2019, s. 59). Istotna była także wizyta chińskiego admirała Guana Yonfeia w Syrii w połowie 2016 r. Ustalono wówczas, że Chiny dostarczą sprzęt wojskowy, będą sprawowały nadzór nad szkoleniem armii tego kraju i organizowały pomoc humanitarną (Pendrakowska, 2020). Wojskowy spotkał się z szefem syryjskiego resortu obrony, gen. Fahdem Jassem al-Freijem. W czasie wspólnej konferencji Guan powiedział, że Chiny i Syria mają przyjazne stosunki, a chińska armia jest gotowa do dalszego wzmacniania interakcji z Syryjczykami. W odpowiedzi al-Freij oznajmił, że żołnierze ChRL aktywnie pracują nad intensyfikacją kooperacji i komunikacji z ich syryjskimi odpowiednikami (Zreik, 2019, s. 63). Od tego momentu Syrię mieli regularnie odwiedzać chińscy doradcy wojskowi. Symptomatyczne jest to, że w 2016 r. Biuro Międzynarodowe Centralnej Komisji Wojskowej ChRL zasugerowało, że chce wzmocnić kontakty wojskowe z Damaszkiem (Ursyński, 2020). Można to odczytywać jako poważniejsze niż do tej pory potraktowanie kwestii syryjskiej przez Chiny, gdyż od lat 80. XX wieku pozostają one państwem blisko związanym z Iranem, wspierając potajemnie jego program nuklearny i antyamerykańską retorykę. Należy także pamiętać, że w połowie 2016 r. sytuacja na froncie zaczęła się przechylać na korzyść Baszara al-Asada, co dodało rządowi w Pekinie kolejny argument na rzecz pogłębienia współdziałania z nim. 
Wreszcie, w tym czasie na Bliskim Wschodzie istotną rolę odgrywało Państwo Islamskie, obecne szczególnie na terenie Syrii i Iraku. Wprawdzie Chińczycy z dystansem podeszli do działalności ISIS i konsekwentnie odmawiali wsparcia Zachodu w walce $\mathrm{z}$ terrorystami, to wraz z biegiem czasu dostrzegali możliwość destabilizacji wewnętrznej z powodu działania wspomnianej organizacji. Dlatego w tym czasie Chiny zaczęły coraz bardziej podnosić kwestię walki z szeroko pojętym terroryzmem, oskarżając Zachód o stosowanie podwójnych standardów w walce $\mathrm{z}$ terroryzmem i przyczynienie się do powstania Państwa Islamskiego jako skutek takiego właśnie ingerowania $\mathrm{w}$ wewnętrzne sprawy niezależnych podmiotów państwowych (Kaczmarski, 2016). Jest wielce prawdopodobne, że owa kooperacja dotyczy problemu Ujgurów, walczących po stronie ISIS. Nawet ambasador syryjski w Chinach przyznaje, że w szeregach sił ISIS walczy około $4-5$ tys. dżihadystów ujgurskich. W celu ich zwalczania Syria współpracuje z władzami w Pekinie - zaznacza z kolei dyplomata R. Pickrell (Pickrell, 2017). Ustawa antyterrorystyczna z 2015 r. zezwoliła chińskim siłom bezpieczeństwa na rozmieszczenie za granicą sił zbrojnych na rzecz zwalczania terroryzmu, a doradcy wojskowi zostali wysłani do Syrii na początku 2017 r. Niniejsza zmiana wzmocniła zdolność Chin do rozlokowania wojska za granicą (Xu, 2017, s. 2). Mimo wszystko Chiny nie były skłonne do wkroczenia na teren Syrii, gdyż nie leży to w interesie komunistycznego mocarstwa. Według Adriana Brony, walka z Państwem Islamskim stanowiła kluczowe znaczenie dla Chin, ponieważ ISIS dążył do utworzenia swoich komórek w Xinjiangu, co może oznaczać groźny precedens i przyczynić się do osłabienia kontroli władz centralnych nad zamieszkałymi tam muzułmanami. Ponadto Ujgurzy rozszerzyli swoją działalność poza granicami zbuntowanej prowincji. Dodatkowo członkowie ISIS stwarzali problem dla ekspansji Chin w regionie i stanowili zagrożenie dla dostaw do tego kraju azjatyckiego ropy naftowej. Wreszcie, rząd w Pekinie wyrażał zaniepokojenie, że walczący po stronie Państwa Islamskiego Ujgurzy po powrocie do kraju mogliby zintensyfikować działalność terrorystyczną i przyczynić się do destabilizacji Państwa Środka od wewnątrz. $Z$ tego też względu Chiny będą popierać rząd Asada (Brona, 2018, s. 237-238).

Niezależnie od powyższych twierdzeń, zdaje się, że chińskie obawy są wyolbrzymione, ponieważ ISIS miało w swoich szeregach niewielką liczbę 
Ujgurów, nie będących niezależną jednostką. Ujgurzy nie przeprowadzili też żadnych ataków poza Syrią oraz Irakiem (Soliev, 2019, s. 73). Co prawda, w Państwie Islamskim byli obecni przedstawiciele Islamskiej Partii Turkiestanu, walczący w prowincji Idlib, zdominowanej przez przeciwnych prezydentowi rebeliantów (Ursyński, 2020), jednak nie odgrywała ona istotnej roli. Akcentowanie działalności Ujgurów wśród islamskich terrorystów służyło też KPCh jako pretekst do zaostrzenia polityki wewnętrznej. Od początku protestów w Syrii chiński reżim obawia się, że sytuacja na Bliskim Wschodzie może doprowadzić do osłabienia kontroli nad ludnością, mogącą pod wpływem procesów politycznych oraz relacji w mediach społecznościowych przejawiać większy krytycyzm wobec rządzącej w Chinach partii komunistycznej i próbować wyrazić odmienne zdanie w różnych sprawach. Dlatego nie chce on za wszelką cenę dopuścić do demokratyzacji Syrii i przejawia wolę dalszego poparcia dla Asada, niezależnie od jego międzynarodowej reputacji.

Innym elementem strategii Chin w Syrii jest strach sprawujących władzę komunistów, że odsunięcie obecnego dyktatora od władzy, reprezentującego autorytarny styl rządzenia i sceptycznego wobec polityki krajów zachodnich, mogłoby doprowadzić do zwiększenia wpływów Zachodu. Pomimo tego, że Arabska Wiosna oraz protesty społeczne, m.in. w Egipcie, niejednokrotnie przybierały antyzachodni charakter i były skierowane często przeciwko proamerykańskim autokratom, chińscy decydenci słusznie doszli do wniosku, że kraje zachodnie, szczególnie Stany Zjednoczone, będą chciały ponownie przejąć kontrolę nad poszczególnymi krajami bliskowschodnimi i ich złożami ropy naftowej oraz gazu. Przedstawiciele KPCh są świadomi, że relacje z Syrią, zarówno na płaszczyźnie politycznej, jak i ekonomicznej, są niemile widziane w Waszyngtonie oraz innych stolicach, co powoduje, że Chiny nie mogą jawnie poprzeć działań syryjskiego przywódcy. Dowodem na to są słowa wypowiedziane w 2016 r. przez brytyjskiego stałego przedstawiciela przy ONZ, Matthew Rycrofta, który stwierdził w ostrych słowach, że Chiny zdecydowały się stanąć po stronie despoty. Rok później w podobnym tonie wypowiedziała się ambasador USA w ONZ, Nikki Haley, która zaznaczyła, że władze Rosji i Chin popełniły błąd nie wyrażając zgody na ustąpienie Asada (Gegout, Suzuki, 2020, s. 381). Jakkolwiek ChRL mogłaby ze spokojem przyjąć jego odejście, godząc się na mianowanie na jego miejsce polityka 
bardziej koncyliacyjnego, a także nastawionego antyzachodnio i realizującego interesy chińskie, rosyjskie oraz irańskie. Podstawę do takich stwierdzeń mogą dać słowa rzecznika MSZ Chin Hua Shunyinga. Powiedział on, że wszystkie strony sporu powinny podjąć negocjacje i trzeba wprowadzić stałe zawieszenie broni (Zreik, 2019, s. 60). Zbliżoną postawę reprezentują analityczki J. Staats oraz J. Chang, zdaniem których Chiny nie nalegały, aby Asad pozostał za wszelką cenę u władzy i raczej zaakceptowałyby wynegocjowaną umowę między nim a opozycyjnymi grupami wspieranymi przez społeczność międzynarodową. Krytykując niedostateczną pomoc Chin dla syryjskich uchodźców, publicystki sugerują, że działania chińskie nie dążą do zakończenia konfliktu, a jedynie służą przygotowaniu gruntu do opanowania ekonomicznego Syrii po wojnie (Staats, Chang, 2017). Wymagająca odnotowywania jest wypowiedź Yixianga Xu. Uważa on, że chińskie wysiłki dyplomatyczne wobec Syrii koncentrują się bardziej na zapobieganiu zmianom demokratycznego reżimu kierowanego przez Zachód, możliwych do zaakceptowania przez konkurencyjne potęgi regionalne (Xu, 2017, s. 4). Także chiński analityk Qu Xing zauważa, że jeśli Liga Państw Arabskich dojdzie do porozumienia ze wszystkimi zainteresowanymi stronami w Syrii w kwestii ustąpienia dyktatora, to Chiny nie będą mieć trudności z zaaprobowaniem tego stanu rzeczy (Gegout, Suzuki, 2020, s. 394).

Nie można też wykluczyć, że poprzez kwestię syryjską Chiny chcą wzmocnić swoje stosunki z Moskwą i osłabić pozycję Stanów Zjednoczonych na Bliskim Wschodzie. Taki pogląd wyraża Michael Swaine. Dla niego stanowisko chińskich władz jest motywowane częściowo chęcią zacieśnienia więzi z Rosją, której wsparcie strategiczne jest bardziej znaczące niż wielu krajów arabskich (Swaine, 2016, s. 8). Jako chęć wzmocnienia relacji z Kremlem można też odczytać poparcie Chin dla formatu astańskiego w Syrii, zapoczątkowanego przez Rosję, Turcję oraz Iran jako „cenne uzupełnienie rozmów pokojowych w Genewie” (Calabresse, 2019). Chińska opinia publiczna uważa operacje rosyjskie za oznakę strategicznej porażki Zachodu i katastrofy wynikającej z jednostronnej polityki USA (Xu, 2017, s. 2). Jednakże w rzeczywistości zasadny będzie wniosek, że dla Chin działania rosyjskie są niezwykle użyteczne, gdyż odciągają uwagę amerykańskiej administracji od pogarszających się w ostatnim czasie wzajemnych relacji, w sytuacji stopniowej utraty znaczenia międzynarodowego USA (Bielicki, 207). Trzymając 
się na uboczu, Chińczycy pogarszają zarazem wizerunek m.in. Rosji, która ze względu na inwazję na Afganistan w 1979 r. oraz kampanię wojenną w Syrii jest w dalszym ciągu postrzegana przez zachodnią opinię publiczną jako agresor. Jak trafnie zauważa Kazimierz Woycicki, Chinom zależy na jak najdłuższym przeciąganiu „syryjskiej awantury” z powodu osłabiania się zarówno Moskwy, jak i Waszyngtonu, co ułatwia chiński podbój Afryki (Woycicki, 2016). Wymowne jest, że portal Sina-Com, powiązany z chińskimi władzami, zasugerował w marcu 2020 r., że armia syryjska powinna zmodernizować system obrony powietrznej, oparty głównie o rosyjską technologię wojskową, oraz kupić baterie systemu przeciwlotniczego HQ 16 i HQ-9, produkowane przez chińską firmę CPIMEC (Chinese CPIMEC offered HQ-16 and HQ 9, 2020). Podobnie ma się rzecz z podejściem Chin wobec Stanów Zjednoczonych. Nie można wykluczyć, że poprzez promowanie obrazu swego państwa jako stojącego na uboczu wydarzeń w Syrii i umiarkowanego aktora tego sporu, realizującego własne interesy geopolityczne na Bliskim Wschodzie, Chiny chcą osłabić pozycję Stanów Zjednoczonych w regionie i zaprezentować się, tak jak w Afryce, jako swoistą alternatywę dla nieudolnej polityki Stanów Zjednoczonych. Ponadto nie jest wykluczone, że ewentualne wciągnięcie Amerykanów w konflikt w regionie arabskim spowoduje zmniejszenie zainteresowania Waszyngtonu problemami Azji Wschodniej oraz Pacyfiku, nieporównywalnie ważniejszych dla chińskiej dyplomacji niż kwestia syryjska. Według Marty Szmagier jednym z powodów aktywności Chin w Syrii jest fakt, że chcą one utrzymać zdobytą w XXI wieku pozycję gospodarczą, kosztem Stanów Zjednoczonych. Analityczka zaznacza, że w USA odnotowywano z niepokojem utratę prymatu USA w dziedzinie kontroli światowych zasobów ropy i gazu, datowanej jeszcze na lata 90. XX wieku. Wraz z początkiem XXI wieku i gwałtownym rozwojem gospodarki chińskiej to właśnie Chiny podpisywały z krajami arabskimi, w tym z Syrią, coraz więcej umów handlowych, dzięki którym pozyskiwały stopniowo państwa bogate w zasoby naturalne, co doprowadziło do osłabienia pozycji Waszyngtonu w globalnej rozgrywce (Szmagier, 2014, s. 66). Dlatego Chiny, chcąc utrzymać obecny stan rzeczy, nie chcą zrażać do siebie krajów arabskich, w tym Syrii, w której jest dużo złóż uranu. Dla Państwa Środka utrzymywanie dotychczasowej polityki neutralności, przy jednoczesnym zawieraniu transakcji gospodarczych ze wszystkimi podmiotami w regionie, 
stanowi bardzo wygodną sytuację, gdyż nie jest ono uwikłane w żadne poważniejsze konflikty natury politycznej i religijnej. Jakkolwiek trudno stwierdzić, czy władze chińskie nie będą wraz z upływem czasu zmuszone do większej aktywności stricte dyplomatycznej, ze względu na osłabienie Stanów Zjednoczonych i Rosji na Bliskim Wschodzie, w tym w Syrii (Bielicki, 2018, s. 37). Na chwilę obecną taki scenariusz jest jednak mało realny, tym bardziej, że w opinii chińskich ekspertów od polityki międzynarodowej pojawiają się głosy o drugorzędności konfliktu syryjskiego w strategii dyplomatycznej Chin (Lavi, Orion, 2019, s. 4).

\section{Działania ChRL wobec wojny hybrydowej w Syrii na płaszczyźnie gospodarczej}

Analizując działania Chin wobec wojny hybrydowej w Syrii na płaszczyźnie ekonomicznej, należy pamiętać o relacjach gospodarczych obu podmiotów. Arabska Wiosna i protesty w Syrii przyczyniły się do gwałtownego ograniczenia handlu między oboma podmiotami. O skali trudności niech świadczy fakt, że w okresie od 2002 do 2009 r. oba państwa podpisały kontrakty gospodarcze i handlowe na łączną kwotę 800 milionów dolarów, a sprzedaż chińskiej broni do Syrii wzrosła trzykrotnie (Deen, 2011). Niewątpliwie do rozwoju wcześniejszej współpracy przyczyniły się ustalenia z 2004 r., kiedy to powstała Syryjsko-Chińska Rada Biznesu (M. Szmagier, 2014, s. 68). Pomimo to w 2010 r. chińskie inwestycje w Syrii wyniosły zaledwie 16,6 mln dolarów (Lavi, Orion, 2019, s. 2). Z czasem jednak stopniowo powiązania gospodarcze były odbudowywane. W lutym 2015 r. Chiny i Syria podpisały umowę w sprawie dostarczenia pomocy humanitarnej i intensyfikacji kooperacji gospodarczej (Zreik, 2019, s. 63), lecz dalej kontakty ekonomiczne chińsko-syryjskie nie były pogłębione w sposób satysfakcjonujący władze w Damaszku. Od 2016 r. coraz istotniejszą rolę w relacjach chińsko-syryjskich odgrywał problem potencjalnej odbudowy Syrii. Pomóc w tym może realizowana przez władze chińskie inicjatywa Nowego Jedwabnego Szlaku i plany włączenia w nią Syrii (Kaczmarski, 2015). Inicjatywa Xi, przedstawiona podczas jego wizyty w Kazachstanie w 2013 r., została odebrana w Damaszku z nadzieją, że może przyczynić się do szybkiej odbudowy gospodarczej pogrążonego w wojnie domowej państwa. Wyraźnie widać, że 
wyraża ono zainteresowanie uczestnictwem w projekcie, czego dowodem są słowa Buthiny Shaaban, doradczyni Asada, że chiński projekt „nie jest” Jedwabnym Szlakiem, jeśli nie przechodzi przez Syrię, Irak i Iran (Dorsey, 2020).W ramach inwestycji gospodarczej Pasa i Szlaku wybrzeże Syrii może odegrać znaczną rolę „przemysłowego portu łączącego”, mającego w założeniu połączenie Zatoki Perskiej, Morza Arabskiego, Morza Czerwonego i Śródziemnego. Przyczynić się do tego ma ekspansja gospodarcza Chin. Jak napisał Joel Wuthnow, firma Sinochem z ChRL posiada 50 procent udziałów w jednym z największych pól naftowych w Syrii (Szmagier, 2014, s. 68). Warte uwagi jest to, że chińskie firmy budowlane rozważają również budowę linii kolejowej łączącej Bejrut i Trypolis w Libanie z Homs i Aleppo w Syrii. Chiny zasugerowały, że Trypolis mógłby stać się specjalną strefą ekonomiczną w projekcie Jedwabnego Szlaku i służyć jako ważny punkt przeładunkowy między Chinami a Europą (Dorsey, 2020), co przy okazji przyczyniłoby się do wzrostu znaczenia dyplomatycznego i strategicznego Syrii.

Wraz z upływem czasu politycy chińscy coraz wyraźniej deklarowali wsparcie dla zniszczonego wojną państwa. W swoim przemówieniu programowym, wygłoszonym w Genewie w styczniu 2017 r., przewodniczący Xi zobowiązał się do zapewnienia 30 milionów dolarów pomocy humanitarnej dla uchodźców i wysiedleńców w Syrii (Calabresse, 2019). W listopadzie tegoż roku ambasador Syrii w Chinach powiedział, że jego kraj będzie skłonny dostarczać ChRL ropę w zamian za pożyczki i korzystać z nich za pośrednictwem juana, zgodnie z aspiracjami Chin do włączenia swojej waluty do globalnego rynku walutowego (Lavi, Orion, 2019, s. 2). Jako znak ofensywy gospodarczej Chin można też odczytać wypowiedź ambasadora Chin w Syrii Qi Qianjina z lutego 2018 r. Powiedział on agencji informacyjnej Xinhua, że powinny one odgrywać większą rolę w procesie odbudowy Syrii, zapewniając większą niż dotychczas pomoc narodowi syryjskiemu (Calabresse, 2019). Parę miesięcy później, w sierpniu tegoż roku, ten sam polityk w swoim artykule twierdził, że chińskie kierownictwo partyjne chce wkroczyć $\mathrm{w}$ „nową erę” pogłębiania partnerstwa $\mathrm{z}$ krajami bliskowschodnimi oraz zwiększenia roli Chin w dążeniach do stabilności na przedmiotowym obszarze. Dyplomata pisał, że Chiny wsparły rząd w Syrii politycznie i humanitarnie, co doprowadziło do opanowania przez Asada 
sytuacji w kraju. Wyraził też gotowość do zacieśnienia więzi we wszystkich wymiarach, deklarując chęć wsparcia przy odbudowie kraju. Ponadto deklarował, że kraj, który reprezentuje, chce wzmocnić wymianę wzajemnej wiedzy w dziedzinach ideologii i kultury, aby przyczynić się do przywrócenia pokoju, stabilności i dobrobytu w Syrii tak prędko, jak to możliwe (Yellinek, 2020, s. 1). W lipcu 2018 r. na konferencji Chiny-kraje arabskie Państwo Środka obiecało przeznaczenie nie tylko 23 milionów dolarów pożyczek na rozwoju regionu, ale także 90 milionów na pomoc humanitarną w określonych konfliktach, m.in. syryjskim (Repetowicz, 2018). W zbliżony sposób wyraził się też prezydent Chin w czerwcu 2019 r. w wywiadzie dla rosyjskich mediów, kiedy to powiedział, że rządzone przez niego państwo jest gotowe uczestniczyć w odbudowie Syrii we własnym zakresie (Lavi, Orion, 2019, s. 1). Właściwe będzie przypuszczenie, że Chiny będą chciały pomóc w odbudowie kraju, inwestując głównie w transport, logistykę i energię (Khan, 2020). Nieprzypadkowo w grudniu 2019 r. Asad z zadowoleniem przyjął zapowiedzi przyrostu chińskich inwestycji, mówiąc, że po „wyzwoleniu" większości obszarów rząd syryjski rozpocznie kompleksowe rozmowy z chińskimi firmami w kwestii odbudowy kraju (Harvey, 2020). Wyrazem przychylnej postawy Chin wobec transformacji gospodarczej Syrii było także spotkanie w marcu 2020 r. szefa Komisji Planowania i Współpracy Międzynarodowej Syrii Imada Sabouniego i obecnego ambasadora Chin w Syrii Fenga Biao. Obaj politycy sygnowali porozumienie o kooperacji ekonomicznej, na mocy którego Chiny przekazały Syrii 14 milionów dolarów w celu zapewnienia pomocy humanitarnej. Była to już piątą część pomocy od 2019 r. (Kobierski, 2020). Mimo wszystko, wydaje się, że jednak wsparcie Chin dla Syrii jest niewystarczające, gdyż obawiają się one zarówno pogorszenia swojego wizerunku w regionie, ale nie są też skłonne do wchodzenia w konflikt z Rosją, potrzebną do niwelowania amerykańskiej presji. Wypada się zgodzić z sinologiem Luke Pateyem, który pisze, że w przeciwieństwie do Afganistanu, gdzie KPCh przekazuje znaczną ilość środków, w Syrii nie chce ona inwestować dużych pieniędzy, czekając na zakończenie wojny. Wtedy, mając jasność sytuacji i nowego układu sił w tym kraju, Chiny będą gotowe zwiększyć swoją pomoc ekonomiczną. Według niego ChRL, w przeciwieństwie do Moskwy, ma niewielkie interesy gospodarcze w Syrii. Chińscy urzędnicy stawiają raczej na utrzymanie funkcjonujących instytucji 
rządowych (Patey, 2016, s. 2-3). Nie jest także jasne, jak epidemia koronawirusa może wpłynąć na chińskie zobowiązania wobec Syrii. Warto pamiętać, że chociaż Chiny na chwilę obecną poniosły najmniejsze straty gospodarcze na skutek pandemii, w porównaniu do skutków wirusa w Stanach Zjednoczonych i w Europie Zachodniej, wzrost ekonomiczny Państwa Środka jest mniejszy niż wcześniej. W dłuższej perspektywie czasowej nie wiadomo, czy Chiny będą w stanie pomagać gospodarczo innym krajom, w tym Syrii. Co prawda, posiadają one znaczne rezerwy ekonomiczne, jednak jest wysoce prawdopodobne, że dla Chin istotniejsze będą inne cele międzynarodowe, bardziej strategiczne w potencjalnej rywalizacji ze Stanami Zjednoczonymi. Poza tym nie chcą one stracić wypracowanej przez ponad dwie dekady dobrej pozycji przetargowej na Bliskim Wschodzie, mając bliskie kontakty ekonomiczne z każdym krajem regionu. Dlatego też Chiny mogą być jedynym krajem zdolnym do długoterminowej pomocy Syrii (Khan, 2020).

\section{Zakończenie}

Podsumowując powyższe rozważania, warto zaznaczyć, że radykalna zmiana stanowiska Chin wobec problemu syryjskiego jest mało prawdopodobna. Chociaż będą one demonstrować coraz większą asertywność na arenie międzynarodowej, w tym na Bliskim Wschodzie, to mało prawdopodobne jest nasilenie ingerencji władz chińskich w sferze politycznej. Działania ChRL w Syrii wpisują się w globalną politykę administracji Xi Jinpinga, zmierzającą do wzmocnienia pozycji kraju i osłabienia wpływów USA przy wykorzystaniu instrumentów gospodarczych. Chińczycy są świadomi, że poprzez kolejne inwestycje na obszarze bliskowschodnim pozyskują sympatię nie tylko władz danych krajów, ale też społeczeństw, mających często uzasadnione pretensje do państw zachodnich za wieloletnią grabież bogactw naturalnych. Dlatego w przypadku niepodjęcia żadnych zmian w polityce krajów anglosaskich wysoce realne jest utrwalenie wpływów ChRL, przedstawiającej się jako bezstronny aktor, dążący do poprawy warunków życia ludności zamieszkującej państwa regionu. Rządzący w Chinach próbują ponadto wykorzystać fakt, że większość krajów Bliskiego Wschodu, w tym Syria, ma napięte stosunki ze Stanami Zjednoczonymi. Poprzez kontakty z Chinami m.in. Turcja oraz częściowo Arabia Saudyjska chcą się uniezależnić od 
amerykańskiego protektoratu i zbudować oparte na większej samodzielności relacje z Chinami, które są przez nie postrzegane jako wzór do naśladowania w dziedzinie rozwoju ekonomicznego, ale również w utrzymaniu stabilności własnego systemu politycznego. Część państw położonych na omawianym obszarze, rozczarowanych nieskutecznością przemian politycznych, a szczególnie ekonomicznych po Arabskiej Wiośnie, z zainteresowaniem patrzy na fenomen rozwoju Chin. W celu utrwalenia przez nie kontroli ekonomicznej nie można wykluczyć, że w przyszłości w regionie dojdzie do rozlokowania sił Chińskiej Armii Ludowo-Wyzwoleńczej. Choć w sierpniu 2018 r. specjalny wysłannik Chin do Syrii, wspomniany wcześniej Xie Xiaoyan, wyraził się z dezaprobatą o potencjalnym wysłaniu chińskiej armii do Syrii, wskazując, że jego kraj akcentuje konieczność pokojowego rozwiązania sporu bez użycia sił zbrojnych (Repetowicz, 2018), to jednak nie ulega wątpliwości, że oddziały chińskie w ostatnich latach coraz intensywniej przygotowują się do udziału w misjach zagranicznych. Przykładem jest stacjonowanie chińskich żołnierzy w Dżibuti (Bielicki, 2018, s. 33) oraz komunikaty chińskiej agencji informacyjnej Xinhua, cytującej wyższego oficera ChAL-W o konieczności wzmocnienia więzi wojskowych z Syrią (Yellinek, 2020, s. 1). Możliwe jest również rozmieszczenie prywatnych firm ochroniarskich, odpowiadających za ochronę inwestycji firm z Państwa Środka. Jednakże w warunkach trwającego konfliktu i pandemii COVID-19 wysoce wątpliwe pozostaje pogłębienie zaangażowania Chin w Syrii. Z dużą dozą prawdopodobieństwa można stwierdzić, że dotychczasowa polityka KPCh w Syrii będzie kontynuowana.

\section{DR PAWEŁ BIELICKI}

Towarzystwo Azji i Pacyfiku ul. Lubicka 44, 87-100 Toruń bielicki11@gmail.com

\section{Bibliografia}

Bielicki, P. (2016). Instrumenty polityki rosyjskiej w konflikcie syryjskim - część 1, Sensus Historiae, 3, 193-211. 
Bielicki, P. (2018). Uwarunkowania polityczno-ekonomiczne polityki Chińskiej Republiki Ludowej na Bliskim Wschodzie, Polityka i Społeczeństwo, 2, 22-40.

Brona, A. (2018), Chińska strategia na Bliskim Wschodzie w XXI wieku - ewolucja kluczowych elementów, Krakowskie Studia Międzynarodowe, 3, 229-242.

Caffero, G. (2020, 10 lutego). China plays the long game on Syria. Pobrane z: https://www. mei.edu/publications/china-plays -long-game-syria.

Calabresse, J. (2019, 9 lipca), China and Syria: In War and Reconstruction. Pobrane z: https://www.mei.edu/publications/china-and-syria-war-and-reconstruction.

China's Peace Plan for Syria (2012, 6 marca). Pobrane z: https://www.voanews.com/ archive/chinas-peace-plan-syria.

Chinese CPMIEC offered HQ 16 and HQ 9 ADS to Syrian regime: reports Sina. (2020, 15 marca), Pobrane z: https://www.globaldefensecorp.com /2020/03/15/ chinese-cpmiec-reached-out-to- syrian-regime-to-sale-hq-16-and-hq-9-ads-reports-sina/

Cordesman, A. (2000). Syria and Weapons of Mass Destruction. New York: Praeger. Pobrane z: http://www.middle-east-info.org/league/syria/syriawmd.pdf.

Deen, T. (2011, 9 czerwca). Russia, China shield Syria from possibile UN sanctions, Pobrane z: https://original.antiwar.com/deen/2011 /06/09/russia-china-shield -syria-from-possible-un-sanctions $\% \mathrm{C} 2 \% \mathrm{~A} 0 /$.

Dorsey, J.M. (2020, 17 lipca). Syria Is Tempting, But Will China Bite? Pobrane z: https:// besacenter.org/perspectives-papers/syria-reconstruction-china/.

Douidri, H., Alex, K. (2018). Scenarios for Syria Atlantisch Perspectief, Stichting Atlantische Commissie, Vol. 42, No. 4, 29-34.

Freedman R.O. (1982). Soviet Policy Toward the Middle East Since 1970. New York: Praeger.

Geogut C., Suzuki S., (2020) China, Responsibility to Protect, and the Case of Syria, Global Governance, 26, s. 379-402.

Gostomczyk, B. (2017). Definicje wojny hybrydowej i jej postrzeganie przez Rosjan. Wiedza Obronna, 3-4, 62-73.

Grabowska, K. (2015). Próba wyjaśnienia pojęcia i istoty wojen hybrydowych. Świat Idei i Polityki, 14, 259-282.

Harvey, F.J. (2020, 10 czerwca). China shows greater interest in Syria amid pandemic, US tensions. Pobrane z: https:/www.al-monitor.com/pulse/originals/2020/06/china-invest-syria-assad-reconstruction-us-tension.html.

Jureńczyk, Ł. (2018). Chińska Republika Ludowa wobec programu atomowego Iranu po zimnej wojnie. Humanities And Social Science, 1, 33-47.

Kaczmarski, M. (2016, 19 stycznia). Chiny wobec rosyjskiej interwencji w Syrii. Pobrane z: http://www.osw.waw.pl/pl/publikacje/komentarze-osw/2016-01-19/chiny-wobec -rosyjskiej-interwencji-w-syrii.

Kaczmarski, M. (2015, 10 lutego). Nowy Jedwabny Szlak: uniwersalne narzędzie chińskiej polityki. Pobrane z: https://www.osw.waw.pl/pl/publikacje/komentarze-osw/2015 -02-10/nowy-jedwabny-szlak-uniwersalne-narzedzie-chinskiej-polityki.

Khan, S. (2020, 1 marca). China's 'rebuilding' role in Iraq could serve as a template for Syria after years of conflict. Pobrane z: https://thearabweekly. com/ chinas-rebuilding-role-iraq-could-serve-template-syria-after-years-conflict. 
Kobierski, Ł. (2020, 14 marca). China's financial support for Syria. Pobrane z: https:// warsawinstitute.org/chinas-financial-support-for-syria/.

Lavi, G., Orion, A. (2019). Will China Reconstruct Syria? INSS Insight, 1187.

Marszałek-Kawa, J. (ed.). (2014). Globalna potęa Chin. Czynniki i perspektywy. Toruń: Wydawnictwo Adam Marszałek.

Marszałek-Kawa, J., Dmochowski, T. (eds.). (2018). Rozważania o kierunkach współczesnej polityki Chin. Toruń, Wydawnictwo Adam Marszałek.

Ochmann, P., Wojas, J. (2018), Wojna hybrydowa jako przykład umiędzynarodowionego konfliktu wewnętrznego, Studia Prawa Publicznego, 2, 101-121.

Patey, L. (2016). China, The Syrian Conflict, And The Threat Of Terrorism. „Danish For International Studies", Copenhagen, DIIS, 1-4.

Pendrakowska, P. (2016, 9 grudnia). Chiny wobec konfliktu w Syrii. Pobrane z: https://teologiapolityczna.pl/patrycja-pendrakowska-chiny-wobec-konfliktu-w-syrii-tpct-36-

Pickrell, R. (2017, 8 maja). Why are 5,000 Chinese Fighting in Syria's Civil War? Pobrane z: http://nationalinterest.org/blog/the-buzz/why-are-5000-chinese-fighting -syrias-civil-war-20562.

Repetowicz, W. (2018, 20 sierpnia). Coraz większe zaangażowanie Chin w Syrii. Pobrane z: https://www.bankier.pl/wiadomosc/Coraz-wieksze-zaangazowanie-Chin-w-Syrii-4150745.html.

Skoneczny, Ł. (2009). Wojna hybrydowa - wyzwanie przyszłości? Wybrane zagadnienia. Przegląd Bezpieczeństwa Wewnętrznego, 1, 39-50.

Smoleńm K. (2020). Wpływ wojny hybrydowej w Syrii na pozycję Kurdów w regionie Bliskiego Wschodu. Przeglad Zachodni 3, 219-238.

Sokala, P. (2008). Strategia regionalna Chińskiej Republiki Ludowej. Forum Politologiczne, t. 8, 15-46.

Soliev, N. (2019). Uyghur Violence And Jihadism In China And Beyond. Counter Terrorist Trends and Analyses, 11(1), 71-75.

Staats, J., Chang, J. (2017, 7 kwietnia). As U.S. Steps Up Syria Action, Where is China? Pobrane z: https://www.usip.org/blog/2017/04/us-steps-syria-action-where-china.

Swaine, M.D. (2012). Chinese Views of the Syrian Conflict. China Leadership Monitor, $39,1-18$.

Syria zgadza się na plan Annana. ONZ szykuje 250 ludzi. (2012, 2 kwietnia). Pobrane z: https://tvn24.pl /swiat/syria-zgadza-sie-na-plan-annana-onz-szykuje-250-ludzi-ra205694 -3493926.

Szczudlik-Tatar, J. (2012, 8 sierpnia). Stanowisko Chin wobec kryzysu w Syrii. Biuletyn PISM, 1-2.

Szmagier, M. (2014). The Syrian Civil War In The Years 2011-2013. An Analysis Of The Conflict And Its Impact On The Global Security System. Poliarchia, 2, 59-78.

Ursyński,M.(2020,8stycznia).ChinywypełniąpróźnięnaBliskimWschodzie?Pobranez:https://kresy.pl/publicystyka/analizy/chiny-zapelnia-proznie-na-bliskim-wschodzie/.

Woycicki, K. (2012, 1 marca). Syria, Moskwa, Chiny. Pobrane z: http://studioopinii.pl/ kazimierz-woycicki-syria-moskwa-chiny/.

Volodzko, D. (2015, 14 września), How China Helped Cause the Syrian Refugee Crisis. Pobrane Z: https://thediplomat.com/2015/09/how-china-helped-cause-the -syrian-refugee-crisis/. 
Xu, Y. (2017). Evolving Sino-Russian Cooperation in Syria, Washington: US Institute of Peace, $1-4$.

Yang Jiechi Elaborates China's Position on the Syrian Issue. (2012, 1 czerwca). Pobrane z: https://www.fmprc.gov.cn/mfa_eng/wjb_663304/zzjg_663340/xybfs_663590/gjlb_ 663594/2888_663776/2890_663780/t939014.shtml.

Yellinek, R. (2020, 23 marca). China and the Rebuilding of Syria. Pobrane z: https:// www.e-ir.info/2020/03/23/opinion-china-and-the-rebuilding-of-syria/.

Yu-shek Cheng, J. (2016). China's Foreign Policy: Challenges And Prospects. Singapore: World Scientific Publishing.

Zreik, M. (2019). China's Involvement In The Syrian Crisis And The Implications Of Its Neutral Stance In The War. RUDN Journal of Political Science, 1, 51-65. 